\title{
Nový pohled na větné členy v ruské a české syntaxi
}

SLOVÁK, V.: Synkretizmus větných členů v ruštině a češtině. Синкретизм членов предложения в русском и чешском языках. Univerzita Palackého v Olomouci, Olomouc 2020, 166 s. ISBN 978-80-244-5617-1, 978-80-244-5618-8.

Jedná se o syntaktickou práci mladého nadějného lingvisty, absolventa oborů ruská filologie a matematika na UP v Olomouci, externího vyučujícího na Katedře slavistiky FF UP. Zaměření na syntax je třeba vyzdvihnout a uvítat zejména v současné době, kdy je čistě gramatickým tématům, tedy morfologii a syntaxi, věnována v lingvistice pozornost spíše ojediněle.

Předmětem autorova badatelského zájmu i čtyřleté výzkumné činnosti je netradiční, stále aktuální a doposud nevyřešené téma, a to zkoumání nejednoznačných, netypických případů $\mathrm{v}$ systému větných členů, které se vymykají zařazení do tradičního systému. Např. ve slovním spojení обработка информации je možná dvojí interpretace větného členu информациu: na základě kritéria formálního jej lze pokládat za prrívlastek neshodný, na základě kritéria obsahového za předmět. Srov. také např. hledím na koně, kdy na koně je větným členem stojícím na pomezí mezi předmětem a příslovečným určením. Fakt, že přesné rozhraničení není u některých větných členů možné, je syntaktikům znám již odedávna. Někteří se s ním smířili, srov. např. výrok V.Šmilauera v souvislosti s platností předmětnou nebo příslovečnou, že „o leckterý z případů by bylo možno, ne však užitečno, se př́it“ (Novočeská skladba, 1966, s. 225), jiní se pokoušeli rozšírit počet tradičních větných členů o členy další, s jejichž pomocí by se tento problém mohl vyřešit (srov. např. Mrázkovo subjektové určení, Adamcův adjekt aj.). V. Slovák však ve své práci nabízí při zachování tradičního pětičlenného systému větných členů vlastní a zcela originální řešení této problematiky.

Kniha je rozdělena do pěti kapitol. První tři představují teoretická východiska, s nimiž se pracuje ve čtvrté a páté kapitole při vlastní analýze hlavních i rozvíjejících větných členů v rusko-českém srovnávacím plánu.

V první kapitole Synkretizmus (s. 12-19) uvádí autor do problematiky chápání i užívání pojmu synkretizmus v lingvistice. Zatímco čeští lingvisté s termínem synkretizmus pracovali jen ojediněle (srov. zejména pádový synkretizmus) a dávali přednost některému z termínů pro jevy podobné, ${ }^{1} \mathrm{v}$ ruské lingvistice se odborný zájem

1 Zásluhou olomouckých rusistů se však v poslední době také v naší jazykovědě začíná pracovat s lingvistickým synkretizmem v rusko-českém srovnávacím plánu. Srov. VOBOŘIL, L.: Sinkretizm i polifunkcional'nost' v jazyke. Olomouc: Univerzita Palackého v Olomouci, 2014 nebo VOBOŘIL, L., 
o synkretizmus vztahuje již $\mathrm{k}$ 6o. letům 2o. století a v současné době už představuje, především zásluhou V. V. Babajcevové, kompaktní jazykovědnou teorii synkretizmu. V pramenech se uvádí, že poprvé se tento termín objevil v pracích L. Hjelmsleva.

Pojem synkretizmus však nemá v lingvistice zdaleka jednotný výklad, řadí se sem různé termíny pro jevy podobné, označující shodu významů nebo jejich mnohoznačnost, např. neutralizace, polysémie, homonymie, kontaminace, jimž je rovněž v práci věnována pozornost. Ve všeobecně akceptované definici lingvistického synkretizmu V. V. Babajcevové se uvádějí dva jeho významy: první se týká asymetrického dualizmu, druhý se vztahuje $\mathrm{k}$ přechodnosti, ten uplatňuje V. Slovák ve své práci. Jedná se o spojení diferenčních strukturních i významových vlastností jazykových jednotek, které se v jazykovém systému nacházejí v opozici a jsou spojeny přechodnými jevy. Chápe tedy synkretizmus jako „vlastnost jazyka, která se projevuje ve schopnosti jazykové jednotky vyjadřovat komplex významů (lexikálních i gramatických)“(s. 17). Podstatu synkretických jevů pak vysvětluje pomocí termínů zóna synkretizmu a škála přechodnosti.

Velmi př́nosný je podrobný a erudovaný výklad ve druhé kapitole práce Systém větných členů v ruštině a češtině (s. 20-41), jehož cílem je objasnění prř́činy existence synkretických, tj. nejednoznačných větných členů. Nejprve je pozornost zaměřena na historický vývoj formování systému větných členů v ruské lingvistické tradici od M. V. Lomonosova a na komentovaný přehled vybraných názorů na nejednoznačné (synkretické) větné členy, a to jak v ruské lingvistické tradici od počátku 20. stol. do V. V. Vinogradova, včetně rozvoje teorie synkretizmu u ruských lingvistů, tak u českých bohemistů i rusistů od J. Gebauera po nejnovější gramatiky.

Na základě prostudování úctyhodného množství odborných pramenů objasňuje V. Slovák chápání pojmu větný člen a principy dělení větných členů v současné jazykovědě. Př́ičiny vzniku synkretických, nejednoznačných větných členů spatřuje $\mathrm{v}$ popisu větných členů současně $\mathrm{z}$ různých hledisek, nikoliv na základě nějakého dominantního znaku.

$\mathrm{Z}$ hlediska teorie synkretizmu proto dává $\mathrm{k}$ úvaze vymezit větné členy typické a vedle nich větné členy nejednoznačné, tj. synkretické.

K tomu využívá na rozdíl od výše uvedených názorů a hledisek teorii gramatických a funkčně sémantických kategorií A. V. Bondarka, a to ve třetí kapitole Větné členy jako funkčně sémantické kategorie se strukturou funkčně sémantického pole (s. 42-51). To je v syntaxi netradiční a poněkud překvapivé, doposud byla totiž tato teorie uplatňována zejména při výzkumu morfologických kategorií (např. kategorie vidu a aspektuálnost, kategorie času a temporálnost). V. Slovák však přesvědčivě dokazuje,

SLOVÁK, V.: Teoretičeskije i prikladnyje aspekty lingvističeskoj sinkretologii. Olomouc: Vydavatelství Univerzity Palackého, 2015 (rec. NOSKOVÁ, K.: Olomoucká kolektivní monografie o lingvistickém synkretismu. Opera Slavica, 2017, 4, s. 83-87) i články v odborných časopisech. 
že rovněž větné členy lze chápat jako funkčně sémantické kategorie, mají totiž svůj formální i obsahový plán, jsou tvořeny prostředky různých jazykových rovin (kromě syntaktických také morfologickými i lexikálními nebo fonetickými) a odpovídají struktuře funkčně sémantického pole, tj. členění na jádro (kam spadají větné členy typické, v nichž jsou obsah a forma v souladu) a periferii (větné členy netypické, synkretické). Kromě toho může docházet k překrývání jednotlivých částí periferií, tj. ke spojování prríznaků typických pro více větných členů, v takových prrípadech pak autor hovoří o synkretických větných členech přechodných.

Větné členy v pojetí V. Slováka jsou tedy chápány jako vzájemně propojená pole s přechodnými jevy, nikoliv jako uzavřené množiny nemající žádný společný prvek.

Vyložené teoretické premisy jsou v dalších dvou kapitolách, podložených bohatým jazykovým materiálem, konkrétně aplikovány na hlavní i na rozvíjející větné členy.

V kapitole Hlavní větné členy (s. 52-75) je pozornost zaměřena zejména na jejich synkretickou podobu nacházející se na periferii funkčně sémantických kategorií podmětu a predikátu jako do̊sledek nesouladu jejich formální a obsahové stránky.

$\mathrm{V}$ rámci podmětu se sem řadí podmět vyjádřený infinitivem, genitivem záporovým nebo partitivním i některé další méně frekventované jevy. Je chvályhodné, že V. Slovák neopomenul ani podmět několikanásobný vyjádřený však nikoliv tradičně paratakticky, tj. pomocí souřadicích spojek, ale hypotakticky, např. Mamb c omuом cmpozue, Benno s Helenou si něco broukali, jemuž nebyla doposud v syntaktických pracích věnována náležitá pozornost, ačkoliv tyto konstrukce činí př̀i větném rozboru potíže (srov. formálně blízké konstrukce s příslovečným určením průvodních okolností, pokud je predikát ve tvaru singuláru, na což ovšem autor také upozorňuje).

$\mathrm{V}$ rámci predikátu jsou na periferii této funkčně sémantické kategorie řazeny neshodné predikáty vyjádřené imperativem, infinitivem, citoslovcem nebo tvarem ecmb nevztahujícím se k 3. os. singuláru, ale i predikáty vyjádřené slovesem s modálně věcným významem ve spojení s infinitivem. U tohoto způsobu autor upozorňuje na problematičnost určení větněčlenské platnosti infinitivu podle toho, zda u slovesa převládá význam modální, nebo věcný (infinitiv tak může být bud’ součástí složeného predikátu, nebo předmětem).

Kapitola Rozvíjející větné členy (s. 76-132) se zabývá oblastí vymezení předmětu, příslovečného určení i přívlastku, včetně problematiky doplňku a subjektového určení (sémantického subjektu).

U předmětu na periferii je mimo jiné s nadhledem komentován rovněž předmět vyjádřený infinitivem, jehož vymezení je jak v ruštině, tak v češtině obtížné právě k výše zmíněnému odlišení od součásti složeného predikátu.

Oddíl o příslovečném určení je vzhledem $\mathrm{k}$ významové šíři tohoto větného členu rozčleněn do deseti významových druhů. U př́íslovečného určení vyjádřeného předložkovými pády autor upozorňuje na jemné nuance v pojímání nejen odlišných 
druhů př́slovečného určení (např. бeжamb со всех ног - př́slovečné určení způsobu × бежать со страху - příslovečné určení příčiny), ale i odlišných větných členů (např. сделать из кирпича - předmět × сделать из вежливости - př́slovečné určení prríčiny). Jako samostatný druh je ve shodě $s$ českými syntaktiky $\mathrm{k}$ př́slovečnému určení řazeno také př́slovečné určení nástroje a prostředku (např. резать ножом), zatímco v ruské tradici je tento větný člen chápán jako předmět, a př́islovečné určení průvodních okolností (např. прыгнуть со стоном), kdy se v ruské tradici jedná o příslovečné určení způsobu. Mísení významů mnoha druhů přislovečného určení $\mathrm{u}$ sledovaných větných členů vede $\mathrm{V}$. Slováka $\mathrm{k}$ přesvědčení o jejich synkretické povaze.

U př́vlastku je centrem autorova zájmu přílastek neshodný, u něhož se synkretizmus projevuje v největší míre. Srov. např. помощь друга, помощь другy, спуск с горы, kde se z hlediska formálního jedná o prŕívlastky neshodné, zatímco $\mathrm{z}$ hlediska sémantického se $\mathrm{v}$ prvním príkladu vyjadřuje subjekt, ve druhém objekt a ve třetím okolnost. Současně se těmito odlišnými možnostmi pojímání těchto větných členů liší čeští rusisté nebo bohemisté, kteří dávají přednost hledisku formálnímu, od ruských lingvistů preferujících hledisko sémantické. Je třeba ocenit také zasvěcené a detailní rozčlenění výkladu neshodného př́vlastku podle typu substantiv, při nichž stojí (substantiva neodvozená, deverbativní, deadjektivní), čehož pak autor využívá při objasňování příčin vzniku některých synkretických neshodných přílastků.

Problematika doplňku jako větného členu závislého zároveň na dvou větných členech a vymezovaného pouze v české lingvistice je zde vyložena jasně a přitom komplexně. Vzhledem $\mathrm{k}$ tomu, že doplněk nevyjadřuje nové významy ani neplní nové funkce, ale slučuje v sobě více významů a funkcí stávajících, pokládá jej autor i s přihlédnutím $\mathrm{k}$ různorodosti jevů, které se $\mathrm{k}$ němu řadí, jednoznačně za synkretický větný člen. Velmi užitečné $\mathrm{z}$ hlediska didaktického je objasnění odlišení doplňku od jmenné části predikátu a od př́slovečného určení, stejně jako výklad o ruských ekvivalentech českých infinitivních konstrukcí po slovesech vnímání.

Závěr kapitoly o rozvíjejících větných členech tvoří problematika subjektového určení, tj. větného členu označujícího subjekt děje (sémantický subjekt, logický podmět), který však není vyjádřen nominativem (autor se o něm zmiňuje již při výkladu podmětu), např. Мне не спится. Дорогу занесло снегом. Mohou se v něm mísit významy subjektově-objektový, subjektově-okolnostní nebo subjektově-objektově-okolnostní. Autor chápe tento větný člen jako označení pro skupinu synkretických jevů nacházejících se na hranici mezi hlavními a rozvíjejícími větnými členy.

Závěr (s. 133-139) představuje precizní shrnutí získaných poznatků, navíc zde autor porovnává výskyt synkretických větných členů $\mathrm{v}$ ruštině a češtině a na př́kladech dokazuje, že v ruštině se v systému větných členů vyskytují synkretické jevy poněkud častěji než v češtině. 
Netradiční pohled V. Slováka na systém větných členů v ruské a české syntaxi, při němž je v naší jazykovědě využita teorie gramatického synkretizmu a současně teorie funkčně sémantických kategorií se strukturou funkčně sémantického pole, je výsledkem snahy přiblížit se objektivní skutečnosti a učinit krok kupředu v syntaktickém bádání nad nejednoznačně řešenými nebo nedořešenými problémy. Jedná se o práci vyzrálou a fundovanou, myšlenkově i obsahově bohatou, kterou lze pokládat za teoretický přínos nejen pro naši současnou jazykovědnou rusistiku. Její obsah je pro výzkum větných členů natolik zásadní, že eventuální další bádání ve sledované oblasti by bez znalosti této monografie bylo nemyslitelné. Díky jasnému a srozumitelnému výkladu může být i při vysoké odbornosti tato práce využívána také ve vysokoškolské pedagogické praxi v rámci studia ruské filologie.

Helena Flídrová

\section{Literatura:}

NOSKOVÁ, K.: Olomoucká kolektivní monografie o lingvistickém synkretismu. Opera Slavica, 2017,4 , s. 83-87.

VOBOŘIL, L.: Sinkretizm i polifunkcional'nost'v jazyke. Olomouc: Univerzita Palackého v Olomouci, 2014. ISBN 978-80-244-4004-o.

VOBOŘIL, L., SLOVÁK, V.: Teoretičeskije i prikladnyje aspekty lingvističeskoj sinkretologii. Olomouc: Vydavatelství Univerzity Palackého, 2015. ISBN 978-80-244-4867-1.

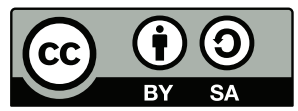

Toto dílo Ize užít v souladu s licenčními podmínkami Creative Commons BY-SA 4.0 International (<https:// creativecommons.org/licenses/by-sa/4.0/legalcode>). Uvedené se nevztahuje na díla či prvky (např. obrazovou či fotografickou dokumentaci), které jsou v díle užity na základě smluvní licence nebo výjimky či omezení príslušných práv.

\section{Про орфоепічну грамотність українців}

ДРУЖИНЕЦЬ, М.Л.: Украӥнське усне мовлення: психо- та соиіофонетичний аспекти. Одеса, 2019. 580 с.

Українську мову здавна вважають однією з наймелодійніших індоєвропейських мов. За евфонічними властивостями їі хтось ставить після французької та перської, хтось порівнює їі з італійською та іспанською. У всякому разі 